\title{
School Feeding Programs in Indonesia
}

\author{
Makiko Sekiyama*1, Takayo Kawakami*2, Reisi Nurdiani*3, Katrin Roosita*3, \\ Rimbawan Rimbawan*3, Nobuko Murayama*4, Hiromi Ishida*5 \\ and Miho Nozue*6
}

${ }^{* 1}$ Graduate Program in Sustainability Science - Global Leadership Initiative (GPSS-GLI), Graduate School of Frontier
Sciences, The University of Tokyo
${ }^{* 2}$ Department of Nutritional Science, Faculty of Health and Welfare Science, Okayama Prefectural University
${ }^{* 3}$ Department of Community Nutrition, Faculty of Human Ecology, Bogor Agricultural University
${ }^{* 4}$ Department of Health and Nutrition, University of Niigata Prefecture
${ }^{* 5}$ Department of Applied Nutrition, Kagawa Nutrition University
${ }^{* 6}$ Department of Health and Nutrition Sciences, Faculty of Health Promotional Sciences, Tokoha University
doi:10.5264/eiyogakuzashi.76.S86

\begin{abstract}
Objectives: In Indonesia, many schools do not have school feeding programs, and children usually buy snacks from school canteens or vendors. The history of the country's school feeding programs is not well documented. This study examined Indonesia's nutritional problems and previous school feeding programs. It also investigated the implementation and related challenges in a current pilot national school feeding program known as PROGAS.

Methods: We conducted situational analysis by reviewing secondary data and the existing literature. We also measured the impact of PROGAS on students' nutritional status.

Results: The review revealed that Indonesia has considerable experience in establishing school feeding programs starting from 1991. The government has established a system from the school to central government level for the quality control, monitoring, and assessment of the pilot program. That program is characterized by its wide scope including improvement in students' dietary intake, promotion of local food, improvement in local agriculture, and community empowerment. However, due to the limited resources allocated to human development, diversity in the country, and difficulty in governance, the low coverage of the program ( $0.05 \%$ in 2013 and $0.14 \%$ in 2016) is still a major challenge. Among the students who joined PROGAS project, nutritional intake significantly increased during the project, while there were no changes in the control group.

Conclusions: Low coverage of the school feeding program is still a major challenge in Indonesia. In the future, government regulations to increase the program's coverage and nutrition education on all forms of malnutrition targeting school-aged children is necessary.
\end{abstract}

Jpn. J. Nutr. Diet., Vol.76 Supplement 1 S86-S97 (2018)

Key words: school feeding program, Indonesia, child nutrition, double burden of malnutrition

\section{Introduction}

The Republic of Indonesia (or Indonesia) consists of about 17,000 islands, stretching from the mainland of Asia to the Pacific Ocean, and is inhabited by approximately 300 ethnic groups. Indonesia is the fourth most populous country in the world, with a population of over 257 million in $2015^{1)}$. The population is still increasing and currently more than half live in urban areas ${ }^{1)}$. Following remarkable economic growth after the end of the economic crisis in 1998, Indonesia is now classified as a lower-middle-income country and the largest economy among the Association of Southeast Asian Nations ${ }^{2}$. Despite this, progress in human development has been slow. In 2014, only $1.1 \%$ of the gross domestic product (GDP) was spent on health and $1.2 \%$ on social protection, which is lesser than that spent in other Southeast Asian countries. Indonesia ranked 110th among 188 countries on the 2015 human development index ${ }^{2)}$.

Disease burden studies by the World Health Organization (WHO) in 1990 and 2010 showed that Indonesia's disease burden has changed from predominantly commu-

Corresponding Author: Makiko Sekiyama. Graduate Program in Sustainability Science - Global Leadership Initiative (GPSS-GLI), Graduate School of Frontier Sciences, The University of Tokyo, 5-1-5, Kashiwanoha, Kashiwa, Chiba 277-8563, Japan Tel: +81-4-7136-4608 Fax: +81-4-7136-4878 E-mail: sekiyama@k.u-tokyo.ac.jp 
nicable diseases to non-communicable diseases over the past two decades ${ }^{3)}$. However, life expectancy has increased steadily from 62 to 69 for men and 65 to 73 years for women, over the past two decades.

The recent Indonesian National Basic Health Survey showed that the prevalence of stunting (height-for-age $z$-score $<-2$ ) and underweight (BMI-for-age $z$-score $<-2$ ) among children aged 5 12 years was $30.7 \%$ and $11.2 \%$, respectively, implying that undernutrition remains a problem among school-aged children ${ }^{4)}$. The same survey also showed that the prevalence of overweight (BMI-for-age $z$-score of $1 \sim 2$ ) and obesity (BMI-for-age $z$-score $\geq 2$ ) has increased rapidly to $10.8 \%$ and $8.0 \%$, respectively, among children aged $<5$ years and school-aged children ${ }^{4}$. Therefore, Indonesian school-aged children face the double burden of malnutrition, which is an increasing public health problem in many low- and middle-income countries $^{5)}$.

One possible approach to address this issue is to help children to develop healthy dietary habits, because childhood is a critical period for growth and development, and for the establishment of dietary habits ${ }^{6)}$. School-based nutrition programs have therefore been implemented worldwide, and the WHO launched the Nutrition-Friendly School Initiative (NFSI) in 2006 to address the double burden of nutrition-related ill health among school-aged children ${ }^{5)}$. NFSI promotes the role of the school in caring for children to prevent malnutrition, because schools have opportunities to educate children and promote healthy dietary and physical activity habits, in cooperation with parents and community members ${ }^{7}$.

In Indonesia, the government began a national school feeding program as part of the national poverty alleviation strategy in the Sixth Five-Year Development Plan in the 1990s. After piloting the program, it was implemented in 1996, targeting elementary school children in villages designated as poor or underdeveloped by the Inpres Desa Tertinggal (IDT) (Presidential Instruction for Villages Left Behind) Program. The program was expanded to all provinces in 1998, targeting 8.1 million children in 53,000 schools. However, because of the severe Asian economic crisis that occurred around 1998, it was canceled ${ }^{8)}$ and the piloting of a new program has only recently started.

This study examined Indonesia's nutritional problems and previous school feeding programs by reviewing sec- ondary data and the existing literature. It also investigated the implementation and related challenges in a pilot national school feeding program, known as Program Gizi Anak Sekolah (PROGAS) or the Nutrition Program for School children.

\section{Methods}

\section{Situational analysis}

We obtained information on the following items from data published by national and international organizations and from the existing literature:

1) National socioeconomic situation;

2) Nutritional status of school children; and

3) Historical and current school feeding programs in Indonesia.

We aimed to identify possible stages of food programs, and for each one, we examined the objectives, related policy, content, quality control, and evaluation. Sources of information included published articles from databases such as Medline, governmental reports, and reports published by international organizations such as the UN. We obtained data on nutritional and health status from the National Basic Health Survey, Riset Kesehatan Dasar (RISKESDAS) $^{4,9,10)}$.

\section{Current national pilot school feeding program}

In 2015, Indonesia started a national pilot school feeding program known as PROGAS. The program provides breakfast during the first school break or at around eight o'clock. The authors were involved in this project, so this paper draws on their knowledge about its objectives, procedures, management, and evaluation.

We measured the impact of PROGAS on student performances. We used an intervention design with two groups: the intervention group received breakfast and the control group did not. This study covered three districts in East Nusa Tenggara, Kupang, Timor Tengah Selatan, and Belu. The subjects were 703 fourth-grade elementary school children: 559 from 14 PROGAS schools and 144 from six randomly selected non-PROGAS schools. We collected data on individual characteristics, morbidities, food consumption, balanced nutrition practice, clean and healthy lifestyle behaviors, weight, and height. Additionally, we obtained the food consumption data using a single 24-hour food recall method by interviewing the school children. 
We applied this method following the methodology of National Dietary Survey called Total Diet Study in Indonesia ${ }^{11)}$. It is reported that this method is generally valid if it is applied to children aged over 10 years ${ }^{12}$. Teachers measured the students' weight and height. We collected baseline data before the program began and the other data in October 2016 (after two months of the implementation of PROGAS). We assessed the energy, protein, and iron intake, weight, and nutritional status of the students who received breakfast, before and after the program. We calculated the nutritional value using an Indonesian food composition table ${ }^{13)}$ and statistical analyses were performed with SPSS, version 20.0 (SPSS Inc., Chicago, IL, USA).

\section{Results}

\section{National socioeconomic situation}

Table 1 shows Indonesia's basic characteristics. The total population in 2015 was over 257 million, with $27.7 \%$ aged 0 14 years ${ }^{1)}$. The GDP sharply increased after the end of the economic crisis in 1998 , reaching $\$ 3,440$ (current $\mathrm{US} \$)^{1)}$.
The primary school net enrollment ratio in 2015 was $89.7 \%{ }^{14)}$, approaching the target of $100 \%$, although several challenges still remain. Specifically, girls have significantly higher drop-out rates than boys do, especially at the secondary level, because of early marriage, and financial and cultural constraints. In remote rural areas, 6.8 million children, mostly of secondary school age, do not attend school $^{2)}$.

Indonesia is an agricultural country and about one third of total national employment is in this sector ${ }^{2}$. The country is pursuing self-sufficiency in rice, corn, soybeans, beef, and sugar, and its overall food security improved between 2009 and 20152). There are strong regional differences, however, and 58 out of 398 districts in rural areas were identified as highly vulnerable to food insecurity in $2015^{2)}$. The country's agriculture is highly vulnerable to climate-related disasters. Appropriate measures are necessary to address regional differences and climate to sustain food security ${ }^{2)}$.

\section{Nutritional status of school children}

Table 2 shows the nutritional status of children. In Indonesia, the National Basic Health Survey, RISKESDAS, started in 2007, and surveys were conducted in 2007,

Table 1 Basic characteristics of Indonesia ${ }^{\dagger}$

\begin{tabular}{ll}
\hline \multicolumn{2}{c}{ Characteristics } \\
\hline Population & $257,563,815$ \\
Population aged 0 14 years in 2015 (\%) & 27.7 \\
Income level & lower-middle-income \\
Gross Domestic Product per capita in 2015 & $\$ 3,440$ (current US $\$ 5$ ) \\
Primary School Gross Enrollment ratio in 2015 (\%) & 105.7 \\
Primary School Net Enrollment ratio in 2015 (\%) & 89.7 \\
Employment in agriculture (\% of total employment) & 34.3 \\
\hline \multirow{2}{*}{ Reference: World Bank 2015 }
\end{tabular}

Table 2 Nutritional status of children in Indonesia in $2013^{\dagger}$

\begin{tabular}{llll}
\hline \multicolumn{3}{c}{ Nutritional indicators } & \\
\hline Prevalence of wasting (weight-for-height $z$ score $<-2$ ) & $\%$ of children under 5 years & $12.1 \%$ \\
Prevalence of underweight (underweight: weight-for-age $z$ score $<-2$ ) & $\%$ of children under 5 years & $19.6 \%$ \\
Prevalence of stunting (stunting: height-for-age $z$ score $<-2$ ) & $\%$ of children under 5 years & $37.2 \%$ \\
Prevalence of overweight (overweight: weight-for for-height $z$ score $>2$ ) & $\%$ of children under 5 years & $11.9 \%$ \\
Prevalence of stunting (stunting: height-for-age $z$ score $<-2$ ) & \% of children $5 \sim 12$ years & $30.7 \%$ \\
Prevalence of thinness (thinness: body-mass-index $z$ score $<-2$ ) & $\%$ of children $5 \sim 12$ years & $11.2 \%$ \\
Prevalence of overweight (overweight: body-mass-index $z$ score $>1$ ) & $\%$ of children $5 \sim 12$ years & $18.8 \%$ \\
\hline
\end{tabular}

$\dagger$ Reference: Riset Kesehatan Dasar 2013 
2010, and 2013. They provide information about the national prevalence of stunting, overweight, and thinness among children under 5 years and school-aged children $^{4,9,10)}$. For children under 5 years, the prevalence of stunting was $37.2 \%$ in 2013 , which had reduced slightly from $36.8 \%$ in 2007 . The prevalence of underweight was around $18 \sim 20 \%$, and that of overweight was around $12 \%$, in all three surveys. For school-aged children, the prevalence of stunting was $30.7 \%$ in 2013 , down from $35.6 \%$ in 2010 (data were not available for 2007). The prevalence of thinness was $11.2 \%$ in 2013 , which had decreased slightly from $13.3 \%$ for boys and $12.9 \%$ for girls in 2007 . The prevalence of overweight among school-aged children, however, had increased rapidly. It was $9.5 \%$ for boys and $6.5 \%$ for girls in 2007, 9.2\% for boys and girls in 2010, and $18.8 \%$ for boys and girls in 2013, showing that around one in five school-aged children are still likely to be overweight ${ }^{4,9,10)}$. These figures clearly show that Indonesian school children are facing the double burden of malnutrition.

\section{History of school feeding programs in Indonesia}

Table 3 summarizes the history of school feeding programs in Indonesia. It can be split into five stages.

First stage (1991 1992; pilot school feeding program)

The first stage of Indonesia's school feeding program started in the early 1990s. The government planned a national school feeding program as part of the national poverty alleviation strategy of the Sixth Five Year Development Plan in the 1990s. Before starting the pilot, the government reviewed studies on school feeding programs elsewhere and conducted efficacy studies on a program in West Nusa Tenggara and West Sumatra Province. As a

Table 3 History of school feeding programs (SFPs) in Indonesia

\begin{tabular}{|c|c|c|c|}
\hline & Stages & Process & Target area \\
\hline 1 & $\begin{array}{l}\text { 1991 1992; pilot } \\
\text { school feeding } \\
\text { program }\end{array}$ & $\begin{array}{l}\text { Review studies on SFP from overseas } \\
\text { Efficacy studies on SFP (West Nusa } \\
\text { Tenggara, West Sumatra) } \\
==>\text { Pilot 1991/1992 in selected schools in } \\
\text { several provinces. }\end{array}$ & $\begin{array}{l}\text { Poor areas of Aceh, West Sumatra, } \\
\text { Central Java, Jogjakarta, Bali, West } \\
\text { Nusa Tenggara, East Nusa Tenggara, } \\
\text { North Sulawesi, Maluku, and Irian } \\
\text { Jaya. }\end{array}$ \\
\hline 2 & $\begin{array}{l}\text { 1996 1997; } \\
\text { implementation in } \\
\text { underdeveloped } \\
\text { villages }\end{array}$ & $\begin{array}{l}\text { Full implementation of the program began in } \\
\text { 1996, targeting elementary schools in villages } \\
\text { designated as poor or underdeveloped by the } \\
\text { IDT Program. }\end{array}$ & $\begin{array}{l}\text { In } 1996 / 97 \text {, the school feeding } \\
\text { program reached } 14,445 \text { villages in } \\
175 \text { districts/city and } 21 \text { provinces } \\
\text { outside Java and Bali, and } 2.3 \text { million } \\
\text { students in } 18,518 \text { public schools and } \\
\text { Islamic public schools. }\end{array}$ \\
\hline
\end{tabular}

1998 2002;

3 implementation in al provinces
National program targeting all provinces. $==>$ Due to the budgetary cut after the economic crisis in 1997 1998, the program stopped in 2002.
All provinces. In 1998 1999, 8.1 million school children in 53,000 schools joined the program; 50.5 million US dollars was used.
In 2010 2011, the target beneficiarie Regional autonomy meant that from 2002, the of the program were expanded to program's budget was provided by the

2010 2011; Re-

4 implementation in 27 out of 33 provinces

regional, rather than the central governm
$==>$ In 2010, school feeding program was started by two government ministries,

\section{include preschool children in 27} the expanded program targeted 1.2 million preschool/elementary school
2016 onwards; pilot

5 trial of Program Gizi

Anak Sekolah (PROGAS)
In 2015, the Indonesian government reinitiated the school feeding program, now known as PROGAS. targeting public elementary school children using a centralized funding scheme.

districts from 27 provinces. In total, children and 180,000 students of Islamic kindergarten and elementary schools.

The program started in July 2016 in three districts in east Nusa Tenggara Province and one district in Banten Province. The program reached 36,547 students in 142 elementary schools.
Provision of snack (15 20\% RDA), nutrition and personal hygiene education, and deworming.

Provision of snack (300 kcal energy \& $5 \mathrm{~g}$ protein, thrice/week, 18 weeks/year), nutrition and personal hygiene education, deworming, school gardens, encouragement for local food production.

Provision of snack $(300 \mathrm{kcal}$ energy \& $5 \mathrm{~g}$ protein, thrice/week, 18 weeks/year), nutrition and personal hygiene education, deworming, school gardens, encouragement for local food production.

Provision of snack (300 kcal energy \& $5 \mathrm{~g}$ protein, 108 days/year with the cost of 2,250 2,650 Rp/snack), nutrition and personal hygiene education, deworming, school gardens, encouragement for local food production.

Provision of cooked dish (energy; 400 500 kcal, protein; 10 12 g, 24 days/session, 4 sessions/year), nutrition and personal hygiene education, deworming, school gardens, encouragement for local food production. 
result, it started a trial program called Program Makanan Tambahan Anak Sekolah (PMT-AS). The pilot ran from 1991 to 1992, in selected schools in several provinces, including the poor areas of Aceh, West Sumatra, Central Java, Jogjakarta, Bali, West Nusa Tenggara, East Nusa Tenggara, North Sulawesi, Maluku, and Irian Jaya.

The objectives of the PMT-AS were:

1) To improve the health and nutritional status of children in primary schools;

2) To improve the learning motivation and capacity of children in schools;

3) To empower parents and the community to be more concerned about their children's schooling, health, and nutrition; and

4) To improve village economies by providing market opportunities for home- or school-produced food products $^{8)}$.

The program included the provision of snacks with $15 \sim 20 \%$ of the recommended daily amount of energy, nutritional and personal hygiene education, and deworming.

Management control and supervision of the pilot was conducted by a central team under the Director-General of Primary and Secondary Education in the Ministry of Education and Culture (MOEC), and a technical team organized separately at the provincial, district/city, subdistrict, village, and school level. Control and supervision included the monitoring of all program activities, including the number of target beneficiaries, funding allocation, implementation, and reporting. Menu/snack planning, including content and portion size, was the responsibility of the technical team, assisted by dietitians from community health centers called Pusat Kesehatan Masyarakat (PUSKESMAS) ${ }^{15)}$. Not all community health centers had a registered dietitian, so registered midwives were sometimes used instead. The evaluation concluded that the pilot had succeeded in reducing the prevalence of worm infections from $67 \%$ to $40 \%{ }^{16)}$.

Second stage (1996 1997; implementation in underdeveloped villages)

Full implementation of the program began in 1996, targeting elementary schools in villages designated as poor or underdeveloped by the IDT Program. In 1996/97, the school feeding program reached 14,445 villages in 175 districts/city and 21 provinces outside Java and Bali, and 2.3 million students in 18,518 public schools and Islamic public schools.

The objectives were expanded as follows:

1) To improve the nutritional status of public and private elementary schools, to improve students' interest in learning, absence, poor grades, and drop-out rates;

2) To support the food diversification program by encouraging children to seek out local snacks in the spirit of the "I love Indonesian Food" movement;

3) To instill good eating habits and a clean and healthy lifestyle since childhood, to ensure that healthy lifestyles are supported by good sanitation;

4) To encourage the development of the economy through the use of local agricultural products, with priority given to the yield of the community group in the IDT program; and

5) To encourage the active participation of the community in the implementation of child education through being aware of their nutritional and health status. This was designed so that if government help was discontinued, the community would be able to continue the program unsupported.

The program provided a midmorning snack 3 days per week throughout the year, or 108 snacks per year. Each snack contained a minimum of $300 \mathrm{kcal}$ energy and $5 \mathrm{~g}$ protein, and the allocated cost of each was approximately US\$ 0.10 0.15. As in the pilot, the snack contained 15 20\% of the recommended daily allowance of energy. The program also provided nutritional and personal hygiene education, deworming, a school garden, and encouragement for local food production ${ }^{8)}$. The management and supervision was the same as for the pilot.

Monitoring and evaluation of the program was conducted monthly ${ }^{17)}$. The head of each elementary school submitted reports to district-level supervisors, who passed them to the head of the district, and then the governor of the province. Reports were also shared at the national level, including with the President. The evaluation found that the program had successfully improved the nutritional status of the children, reduced the school absence rate, and increased the use of traditional foods and local food resources ${ }^{18)}$.

Third stage (1998 2002; implementation in all provinces)

The trial program was expanded to all provinces in 1998, targeting 8.1 million children in 53,000 schools. In 
total, 50.5 million US dollars was used. The program was stopped in 2002, following the severe Asian economic crisis of $1998^{8)}$.

By the expansion stage, the program had the following eight objectives:

1) To increase the attendance of children at school;

2) To increase the physical performance of school children;

3) To increase the popularity of Indonesian foods;

4) To improve behavior related to healthy diet and hygiene;

5) To increase community participation in the supply and use of local food in schools;

6) To increase community participation in health and nutrition education;

7) To improve child health, especially through deworming; and

8) To develop gardening at school and home as a way of learning about agriculture.

The program content, management and monitoring arrangements were the same as the initial roll-out in 1996. The evaluation results showed that the program had improved the income of the families of its beneficiaries, of farmers who provided local foods, and of local cooking groups. It also improved the nutritional status of schoolaged children. The number of the people exposed to information about the importance of nutrition and education increased drastically ${ }^{8)}$.

Fourth stage (2010 2011; Re-implementation in 27 out of 33 provinces)

Regional autonomy meant that, from 2002, the program's budget was provided by the regional, rather than the central government. This caused changes in the regulations for program implementation, depending on the mayor. In 2010, another school feeding program was started by two government ministries, targeting public elementary school children using a centralized funding scheme.

In 2010 2011, the target beneficiaries of the program were expanded to include preschool children in 27 districts from 27 provinces. In total, the expanded program targeted 1.2 million preschool/elementary school children and 180,000 students of Islamic kindergarten and elementary schools ${ }^{19,20)}$.

By this stage, the objectives had been changed to cover the following:

(1) To improve nutritional intake;

(2) To increase physical endurance;

(3) To increase attendance and learning interest;

(4) To increase the preference for local nutritious food;

(5) To improve hygiene and healthy behavior, including healthy eating habits;

(6) To increase community participation; and

(7) To increase community income through the increased use of local products ${ }^{19,20)}$.

In general, the form of the program remained the same as before. The snacks provided at least $15 \%$ of the calorific requirements and $10 \%$ of the protein requirements of the students, by age, with at least $300 \mathrm{kcal}$ and $5 \mathrm{~g}$ of protein $^{19,20)}$. The cost of the snacks for public schools (kindergarten/elementary schools) was Rp 2,500 (US\$ 0.27 in 2010) per portion in western Indonesia and Rp 2,650 (US\$ 0.29 in 2010) per portion in the eastern region. For Islamic schools, the figures were Rp 2,250 (US\$ 0.25 in 2010) in the western region and Rp 2,600 (US\$ 0.28 in 2010) in the eastern region. The total budget in 2011 was Rp 300 billion (US \$34 million dollars). Again, snacks were provided for a total of 108 days per child in 2010 and $2011^{19,20)}$.

The control and monitoring of the program was conducted in several stages from the school and village level, up to the central level. This included the management of the program implementation and reporting. Snack quality was controlled with assistance from dietitians working at community health centers. Monitoring and evaluation was carried out by several groups, including central, provincial, district, subdistrict, village, and school coordinating teams. Evaluation focused on program implementation. A full program evaluation study was conducted and reported by the Education Sector Analytical and Capacity Development Partnership (ACDP), Agency for Research and Development, MOEC.

The evaluation found that, primarily because of a shortage of funds, communication, monitoring, reporting, and quality assurance were less than adequate. Some provincial and district program officials did not know about technical implementation manuals, which should have been an essential element of their training. This inadequate program management negatively affected program implementation ${ }^{18)}$. Therefore, the program did not achieve any significant impact on the nutritional status or overall 
health of school children ${ }^{19)}$. Quantitative data from school records showed that, on an average, students' school attendance improved in the nine program districts by the end of the second year of the program in comparison with that at the baseline. Additionally, an improvement was observed in students' motivation to attend school and in their attention in class. The program also seemed to have had some positive impact on the academic performance of students ${ }^{19)}$. Qualitative evidence gathered from sample program sites suggested that the program had empowered some members of the community through the purchase and distribution of local ingredients and products, and that there had been a certain amount of revitalization in the village family welfare organization (PKK).

Fifth stage (2016 onwards; pilot trial of PROGAS)

After the termination of the school feeding program in 2011, there was no further governmental program in this area in Indonesia, until the start of the PROGAS in 2015.

4. Current school feeding program in Indonesia: Pilot of PROGAS

In 2015, the Indonesian government re-initiated the school feeding program, now known as PROGAS. PROGAS is slightly different from previous programs because it provides complete meals rather than snacks. One reason for this was that previous studies found that calorie and protein intake was insufficient in $35 \%$ and $20 \%$ of schoolaged children in Indonesia, respectively ${ }^{19)}$. The present study therefore addressed this issue ${ }^{19)}$. The survey also showed that $20 \%$ of children ate fewer than three meals per day and $20 \%$ went to school without having breakfast $^{19)}$. Other data showed that $89 \%$ of the population aged over 10 years did not eat enough vegetables and fruits, and only $47 \%$ washed their hands properly before eating ${ }^{4)}$. PROGAS was therefore designed to be more comprehensive than previous programs.

In 2015, the overall guidelines, technical guidelines, and modules associated with the program were published, and funding was started. The program started in July 2016 in three districts in East Nusa Tenggara Province and one district in Banten Province. Before starting the program, the central government team provided training and technical guidance for the implementing team in each of the districts, subdistricts, and schools. This program involves central, provincial, district, and subdistrict governments, and cross-cutting technical offices, especially the health office. The program reached 36,547 students in 142 elementary schools ${ }^{21)}$. In 2015/16, there were 132,381 public elementary and 25,885,053 elementary school students in Indonesia ${ }^{22)}$. The program therefore reached around $0.14 \%$ of the total population.

The program had the following seven objectives:

1) To improve the nutritional knowledge, attitude, and dietary practices of school children;

2) To improve behavior related to healthy diet and hygiene;

3) To improve nutritional intake of school children through encouraging dietary intake based on balanced nutrition guidelines;

4) To increase the physical and mental health of school children;

5) To encourage the development of sanitary and healthy canteens in elementary schools;

6) To encourage children to eat local food; and

7) To increase community participation in using local food.

The program involved the provision of cooked meals on 24 days per session, with four sessions per year. Specifically, breakfast was provided during the first school breaktime or around eight o'clock, at least three times a week, on either alternate or consecutive days. Each meal contained 400 500 kcal energy and 10 12 g protein, or one quarter to one third of the daily nutritional requirements of school-age children, and the menus included dishes prepared using local food. The program also included nutritional and personal hygiene education, deworming, school gardens, and encouragement of local food production.

\section{Management}

PROGAS involved management across several levels, including central, provincial, district, subdistrict, and school. The school committees were usually organized by the parents' association. The duties and responsibilities at each level have been presented in Table 4. Each school's PROGAS implementation team had seven members, including representatives from the district education and health section, and the subdistrict's education section and community health center, the school head, teachers, someone from the school committee as the secretary, a teacher as the treasurer, and members of the cooking team, which included school committee members, repre- 
Table 4 Duties and responsibilities of organizations implementing Program Gizi Anak Sekolah (PROGAS) ${ }^{\dagger}$

\begin{tabular}{|c|c|c|}
\hline Level & Implementer & Duties and Responsibility \\
\hline Central level & $\begin{array}{l}\text { Directorate of Elementary Schools, } \\
\text { MOEC }\end{array}$ & $\begin{array}{l}\text { Establish PROGAS regulations } \\
\text { Popularize PROGAS } \\
\text { Establish target beneficiaries } \\
\text { Distribute PROGAS funds to target schools } \\
\text { Conduct technical guidance } \\
\text { Conduct monitoring }\end{array}$ \\
\hline Provincial level & Provincial Education Office & $\begin{array}{l}\text { Conduct coordination, guidance, and control of the program with the Central } \\
\text { Team and Implementing Team } \\
\text { Socialize the program to the governor and the District Education Office }\end{array}$ \\
\hline District/City level & District/City Education Office & $\begin{array}{l}\text { Conduct monitoring, guidance, and controlling the implementation of PROGRAS } \\
\text { Approves funding withdrawal and accountability report of the use of funds } \\
\text { Conduct supervision and monitoring } \\
\text { Plan for follow up programs }\end{array}$ \\
\hline Subdistrict level & Regent & $\begin{array}{l}\text { Attend the technical guidance } \\
\text { Conduct monitoring, guidance, and controlling } \\
\text { Conduct supervision and monitoring }\end{array}$ \\
\hline School Committee & School Committee & $\begin{array}{l}\text { Attend the technical guidance } \\
\text { Socialize PROGAS to the community } \\
\text { Encourage community participation and the implementation of PROGAS } \\
\text { Evaluate the implementation of PROGAS }\end{array}$ \\
\hline School level & Head of School/Principal & $\begin{array}{l}\text { Conduct the program, attend the technical guidance, form a cooking team } \\
\text { Make modifications of the menu with assistance from the nutritionist of the } \\
\text { Community Health Center } \\
\text { Make a report according to the conditions of the Central Team }\end{array}$ \\
\hline
\end{tabular}

$\dagger$ Reference: Ministry of Education and Culture Republic of Indonesia (Kementerian Pendidikan dan Kebudayaan RI) 2016

sentatives from the village family welfare organization (PKK), and parents ${ }^{21)}$.

The funding was provided by the Ministry of Education and Culture in 2016. The cost of one student's breakfast was Rp 12,000 (including management and cooking group costs). The eating utensils cost was Rp 30,000 per student and that for cooking utensils was Rp 4,500,000 per school. The school management and cooking group had to maintain a balance-book, collect proofs of transactions, and maintain a working report $\mathrm{t}^{21)}$.

The district education section provided monitoring, guidance, and control of the implementation of PROGAS, including the provision of funding, accountability reporting, supervision, monitoring, and arrangements to ensure the ongoing sustainability of the program. The participation of the local community was also important, because community members were involved in the provision of ingredients (fishermen, local sellers, and local distribu- tors), purchase of ingredients, and the preparation, processing, and serving, monitored by the school committee. The cooking team often consisted of parents trained by the PROGAS team and assisted by dietitians from the community health centers in each subdistrict ${ }^{21)}$.

\section{Quality control}

Menu planning was based on the daily nutritional requirements of children aged 7 12 years ${ }^{23)}$. The ingredients chosen had to be local, fresh, and free from contaminants, and they had to include carbohydrate, animal- or plant-based protein sources, and sources of vitamins and minerals. Water had to meet drinking water standards. Three example menus were prepared by the team, but schools were allowed to create their own menu with the help of the dietitian from the local community health center. It was expected that meals would not be repeated within a week, despite problems with food availability.

Before the program was implemented, technical train- 
ing was provided in targeted districts. This was attended by the subdistrict coordinating team, dietitians from community health centers, supervising teams from villages, and heads, teachers, and cooking groups from the target schools. This aimed to train related stakeholders on the nutritional requirements and nutrition guidelines ${ }^{24)}$, including the importance of clean and healthy behavior, menu planning, food processing (including hygiene and sanitation), worm infestations, prevention and treatment of food poisoning, and increasing the role of the community. The school and cooking groups were also trained on how to calculate the ingredients necessary, on the storage and preparation of ingredients, and on the processing, portioning, and serving of breakfast. They were also enabled to develop new menus based on the availability of local foods.

The cooking groups were selected and appointed by each school's PROGAS implementing team. There was a maximum of four groups per school, each comprising four people drawn from the school committee, village family welfare organization (PKK) team, and parents. The cooking team was responsible for calculating the ingredients needed, purchasing, preparing, and processing them, serving breakfast, cleaning all the cooking utensils and reporting each day on the purchase of ingredients to the person in charge or the principal.

Hygiene and sanitation improvements focused on two activities, food processing and food handlers, and school sanitation arrangements. The hygiene and sanitation materials for the food service and food handlers were developed based on the standards for hygiene and food published by the Ministry of Health ${ }^{25)}$. The sanitation of the school was part of the clean and healthy behavior practice run by the school. Both were included in the guidance materials provided during training.

Nutrition education aimed to increase students' knowledge to enable them to apply the guidelines on the four pillars of balanced nutrition ${ }^{23)}$, which include consuming a variety of good quality foods, both in type and amount, behaving in a clean and healthy manner, engaging in sufficient physical activity and exercise, and routinely checking body weight. Teachers provided nutrition education just before the food was provided to the students. The strategy included nutrition education during the provision of breakfast, nutrition education materials integrated into related subjects, messages on nutrition education inserted into extracurricular subjects (scouts, sports, art, and others), and use of communication, information, and education media such as posters, songs, and jingles.

\section{Evaluation}

Monitoring and evaluation was carried out by the central PROGAS team, provincial supervisory team, district/ city development team, subdistrict PROGAS team, and school PROGAS implementing team. It was based on the PROGAS implementation monitoring form developed by the central team and passed to the others. Student-based indicators included the number of students who intended to receive meals, number of students who actually did so, number of days on which food was provided, number of students who did not attend school on those days, number of students who did not attend school on days on which food was not provided, menus served and planned, portions of breakfast served to students, number of students who finished breakfast, number of students who did not finish breakfast, number of students who understand the benefit of having breakfast, number of students who knew what was involved in a balanced diet, number of students who washed their hands before and after eating, and weight and height of students before and after the program $^{21)}$. Administrative indicators included amount of money used in line with the technical guidance, provision of clean water for hand-washing, whether the number of eating and cooking utensils was adequate, source of ingredients, implementation of the principles of good, safe, and timely food processing, timely provision of breakfast to students, number and composition of the cooking team, checking of breakfast menus by the head of the school, implementation of nutrition education by teachers and whether teachers are effective role models for clean and healthy behavior ${ }^{21)}$.

The results of our analysis to measure the impact of PROGAS found a significant increase in energy and protein intake $(p<0.001)$ among the intervention group. However there were no changes in the control group. Similar results were shown in the iron intake (Table 5). Students in the intervention group exhibited an average weight increase of $0.2 \mathrm{~kg}$ in the first two months, and the control group lost an average of $0.1 \mathrm{~kg}$. The nutritional status of the intervention group was better than that of the control group, as shown by the mean $z$-scores of the intervention group (Table 6). 
Table 5. Mean energy and nutrient intake of PROGAS beneficiaries

\begin{tabular}{|c|c|c|c|c|}
\hline & & \multicolumn{2}{|c|}{ Average Intake } & \multirow[b]{2}{*}{$p$ value $^{\ddagger}$} \\
\hline & & $\begin{array}{l}\text { Control } \\
(n=141)\end{array}$ & $\begin{array}{c}\text { Intervention } \\
\quad(n=541)\end{array}$ & \\
\hline \multicolumn{5}{|c|}{ Energy (kcal) } \\
\hline & Before & $971 \pm 387.17$ & $1,107 \pm 481.83$ & 0.371 \\
\hline & During & $972 \pm 467.34$ & $1,572 \pm 609.46$ & $<0.001$ \\
\hline & $p$ value $\mathrm{e}^{\dagger}$ & 0.662 & $p<0.001$ & \\
\hline \multicolumn{5}{|l|}{ Protein $(\mathrm{g})$} \\
\hline & Before & $21.10 \pm 11.75$ & $26.96 \pm 13.92$ & $<0.001$ \\
\hline & During & $22.43 \pm 14.2$ & $37.76 \pm 17.45$ & $<0.001$ \\
\hline & $p$ value ${ }^{\dagger}$ & 0.351 & $p<0.001$ & \\
\hline \multicolumn{5}{|l|}{ Iron (mg) } \\
\hline & Before & $5.79 \pm 3.43$ & $7.38 \pm 4.21$ & $<0.001$ \\
\hline & During & $6.63 \pm 4.67$ & $10.56 \pm 5.32$ & $<0.001$ \\
\hline & $p$ value $^{\dagger}$ & 0.129 & $p<0.001$ & \\
\hline
\end{tabular}

${ }^{\dagger}$ Wilcoxon signed-rank test, ${ }^{\ddagger}$ independent sample $t$-test

Table 6. BMI of targeted children before and after the implementation of PROGAS

\begin{tabular}{|c|c|c|c|}
\hline \multirow[b]{2}{*}{ Body weight } & \multicolumn{2}{|c|}{ BMI (median) } & \multirow[b]{2}{*}{$p$ value $^{\dagger}$} \\
\hline & $\begin{array}{l}\text { Control } \\
(n=144)\end{array}$ & $\begin{array}{c}\text { Intervention } \\
(n=559)\end{array}$ & \\
\hline Before & $(19.9 \sim 25.2)$ & $23.4(20.8 \sim 25.6)$ & 0.018 \\
\hline During & $21.9(20.3 \sim 24.4)$ & $23.6(21.4 \sim 25.8)$ & $<0.001$ \\
\hline$p$ value $^{\dagger}$ & 0.653 & $<0.001$ & \\
\hline
\end{tabular}

$\dagger$ Mann-Whitney U test

\section{Considerations/Recommendations}

Indonesia has considerable experience of running school feeding programs, and it has several achievements to show. For example, the government has been able to develop effective program implementation guidelines, with target criteria, roles and responsibilities of stakeholder organizations, technical program implementation materials, and budgeting, supervising, monitoring and reporting arrangements. It has also developed national regulations, including presidential instructions and regulations from the Minister of Home Affairs. It has provided training for teachers, dietitians, and food handlers in all the target beneficiary areas related to program implementation (menu planning, processing and serving snacks, food safety, nutrition education, and others). The government also carried out a program evaluation on the initial school feeding program (PMT-AS), which showed that the program had positive effects for the children, school, parents, local farmers, and food sellers.
Despite this, the coverage of the school feeding program in Indonesia is low; it was just $0.05 \%$ in $2013^{26)}$. PROGAS covered only four districts in Indonesia in 2016, involving 36,547 students from 142 elementary schools, or $0.14 \%$ of the elementary school students in Indonesia. Children in other schools usually buy snacks from school canteens or other vendors.

There are three main difficulties in providing a school feeding program in Indonesia. First, there are limited resources allocated to human development: only $1.1 \%$ of the GDP was spent on health and $1.2 \%$ on social protection in 2014, which is less than that spent in other Southeast Asian countries ${ }^{2)}$. The allocated cost of the school feeding program was $0.01 \%$ of the GDP ${ }^{26)}$. More recently, however, the government has started to prioritize spending on human development and it seems likely that school feeding programs could be prioritized as part of an ongoing development policy.

The second difficulty is the diversity in the country. Indonesia is the fourth most populous country in the world, and is spread across a vast area. There are huge regional differences, especially between Java Island, where $60 \%$ of the country's population lives, and outer Java. The government has placed a developmental priority on remote areas, and has set clear criteria for selecting program beneficiaries, but the size of the population to be covered is still large and selecting locations remains a challenge. The third difficulty is governance. Previous school feeding programs established organized systems 
for quality control, monitoring, and assessment, but the evaluation report on the 2010 2011 program revealed problems with communication and management at all levels. These negatively affected program implementation $^{18)}$

For the future, there are a number of measures that would improve the school feeding program in Indonesia. First, it is essential to increase the coverage of such a program. This may require government regulations to mandate sustainability and coordination among government agencies. Second, PROGAS needs to be managed to provide evidence of its effectiveness and outcomes. The previous program showed some positive effects on the academic motivation of students, consumption of local food, and economic empowerment of local communities. Our analysis of PROGAS also showed some positive effects on the nutritional intake and nutritional status of children. However, the previous program suggests that it may be helpful to strengthen coordination among stakeholders, especially between the central and local government, and improve planning, organizing, and monitoring $^{18)}$. Third, it may be helpful to provide nutrition education in other schools, especially considering the low coverage of the current school feeding program. Indonesia's children have a double burden of malnutrition: high proportions of both under- and over-nourished children. In remote areas, food insecurity and undernutrition are the main issues to be addressed. However, around one in five school children is overweight, so nutrition education among school-aged children needs to cover both issues. Nutrition education should be included in the curriculum, to encourage healthy dietary habits among children.

This study had several limitations. First, there is not much information about implementation at the regional level, especially for the period from 2002 to 2010, when there was a focus on regional autonomy. Documents reporting on the school feeding program during that stage are very limited. Second, the historical review section of this study was mainly based on documentary sources. Future studies may wish to interview some of those involved in the implementation of such programs, including those from central government ministries.

\section{Conclusions}

Indonesia has considerable experience in establishing school feeding programs. The government has established a system from the school to central government level for the quality control, monitoring, and assessment of the current school feeding program. This program is characterized by its wide scope, including the improvement of dietary intake of students, the promotion of local food, and the improvement of local agriculture and community empowerment. However, the low coverage of the program is still a major challenge. For the future, government regulations may be necessary to increase program coverage, and the program's management should be improved. Nutrition education targeting all forms of malnutrition is also necessary for school-aged children.

\section{Conflict of Interest}

The authors declare no conflicts of interest.

\section{References}

1) World Bank: Indonesia country profile. http://www. worldbank.org/en/country/indonesia (Accessed March, 17, 2017)

2) WFP: Country Programme Indonesia 200914 (20162020) (2016) WFP, Rome

3) Global burden disease profiles: Indonesia Seattle, WA, USA: Institute of Health Metrics and Evaluation. http:// www.healthdata.org/sites/default/files/files/country_ profiles/GBD/ihme_gbd_country_report_indonesia.pdf (Accessed November, 22, 2016)

4) National Institute of Health Research and Development Riset Kesehatan Dasar 2013 (2013) Ministry of Health, Republic of Indonesia, Jakarta

5) Delisle, H.F., Receveur, O., Agueh, V., et al.: Pilot project of the Nutrition-Friendly School Initiative (NFSI) in Ouagadougou, Burkina Faso and Cotonou, Benin, in West Africa, Glob. Heal. Promot., 20, 39-49 (2013)

6) Skinner, J.D., Carruth, B.R., Wendy, B., et al.: Children's food preferences: A longitudinal analysis, J. Am Diet. Assoc., 102, 1638-1647 (2002)

7) World Health Organization: Report of the Brainstorming Meeting on the development of a framework on the Nutrition-Friendly Schools Initiative. http://www.who.int/ nutrition/publications/Montreux_Meeting_Report.pdf. (Accessed April, 25, 2016)

8) Studdert, L.J., Soekirman, Rasmussen, K.M., et al.: Community-based school feeding during Indonesia's economic crisis: Implementation, benefits, and sustainability, Food Nutr. Bull., 25, 156-165 (2004) 
9) National Institute of Health Research and Development: Riset Kesehatan Dasar 2007 (2007) Ministry of Health, Republic of Indonesia, Jakarta

10) National Institute of Health Research and Development: Riset Kesehatan Dasar 2010 (2010) Ministry of Health, Republic of Indonesia, Jakarta

11) National Institute for Health Research and Development: Total Diet Study: Individual Food Consumption Survey (Studi Diet Total: Survei Konsumsi Makanan Individu) Indonesia 2014 (2014) Ministry of Health, Republic of Indonesia, Jakarta

12) Willet, W.: Nutritional Epidemiology (2013) Oxford University Press, New York

13) Hardinsyah, Briawan, D.: Penilaian dan Perencanaan Konsumsi Pangan (Food Consumption Assessment and Planning) Bogor (1994) Institut Pertanian Bogor (Bogor Agricultural University), Bogor (in Indonesian)

14) World Bank: The State of Social Safety Nets (2015) The World Bank, Washington, D.C.

15) Rohimah, I.E.: Studi Keberlanjutan Program Makanan Tambahan untuk Anak Sekolah (PMT-AS) di Bandung dan Bogor [Disertasi] (Study on PMT-AS program in Bandung and Bogor district [Dissertation]) (2002) Institut Pertanian Bogor (Bogor Agricultural University), Bogor (in Indonesian)

16) National Development Planning Agency (Badan Perencanaan Pembangunan Nasional): Pangan dan Perbaikan Gizi (Food and nutritional improvement) (1995) BAPPENAS, Jakarta (in Indonesian)

17) President of the Republic of Indonesia: Instruksi Presiden Nomor 1 Tahun 1997 Tentang Program Makanan Tambahan Anak Sekolah (Instruction of the President of Republic of Indonesia Number 1 Year 1997 on School Supplementary Feeding Program) (1997) Executive Office of the President, Jakarta (in Indonesian)

18) National Development Planning Agency (Badan Perencanaan Pembangunan Nasional): Pangan dan Perbaikan Gizi (Food and nutritional improvement) (1998) BAPPENAS, Jakarta (in Indonesian)
19) Analytical and Capacity Development Partnership (ACDP): Evaluation of the Supplemental Food for School Children Program (2013) Ministry of Education and Culture, Republic of Indonesia, Jakarta

20) Ministry of Home Affairs of the Republic of Indonesia (Kementerian Dalam Negeri RI): Peraturan Menteri Dalam Negeri Nomor 18 Tahun 2011 Tentang Pedoman Penyediaan Makanan Tambahan Anak Sekolah (Ministry of Home Affairs Number 18 Year 2011 on Guideline of School Supplementary Feeding) (2011) KEMDAGRI, Jakarta (in Indonesian)

21) Ministry of Education and Culture Republic of Indonesia (Kementerian Pendidikan dan Kebudayaan RI): Petunjuk Teknis Bantuan Pemerintah, Program Gizi Anak Sekolah (PROGAS) (2016) KEMDIKBUD, Jakarta (in Indonesian)

22) Ministry of Education and Culture, Center for educational data and statistics and culture: Indonesia Educational Statistics in Brief 2015/2016. http://publikasi.data. kemdikbud.go.id/uploadDir/isi_AA46E7FA-90A3-46D9BDE6-CA6111248E94_.pdf (Accessed August, 30, 2017)

23) Ministry of Health of the Republic of Indonesia: Minister of Health of the Republic of Indonesia Regulation Number 75 Year 2013 on Recommended Dietary Allowance for Indonesian People (2013) Ministry of Health, Jakarta

24) Ministry of Health of the Republic of Indonesia: Minister of Health of the Republic of Indonesia Regulation Number 41 Year 2014 on Balanced Nutrition Guidelines (2014) Ministry of Health, Jakarta

25) Ministry of Health of the Republic of Indonesia: Module Hygiene Sanitation Food and Beverage (2006) Ministry of Health, Jakarta

26) WFP: State of School Feeding Worldwide 2013. http:// documents.wfp.org/stellent/groups/public/documents/ communications/wfp257481.pdf?_ga=2.28160638. 313483440.1506958137-1444685948.1506958137 (Accessed September, 18, 2017)

(Received October 3, 2017; Accepted June 5, 2018) 